\title{
Growth and physiology of maize under water salinity and nitrogen fertilization in two soils
}

\author{
Régis dos S. Braz ${ }^{1}$, Claudivan F. de Lacerda ${ }^{1}$, Raimundo N. de Assis Júnior ${ }^{1}$, Jorge F. da S. Ferreira ${ }^{2}$, \\ Adriana C. de Oliveira $^{1} \&$ Aureliano de A. Ribeiro ${ }^{1}$ \\ ${ }^{1}$ Universidade Federal do Ceará. Fortaleza, CE, Brasil. E-mail: regismta@bol.com.br (Corresponding author) - ORCID: 0000-0002-2992-0623; \\ cfeitosa@ufc.br - ORCID: 0000-0002-5324-8195; assisjr@ufc.br - ORCID: 0000-0002-5892-0454; drica_fj@hotmail.com.br - ORCID: 0000-0003- \\ 3931-7913; alburibeiro@hotmail.com - ORCID: 0000-0001-5823-7615 \\ ${ }^{2}$ United States Department of Agriculture/US Salinity Laboratory. Riverside, CA, USA. E-mail: jorge.ferreira@ars.usda.gov - ORCID: 0000-0003- \\ 4550-6761
}

\begin{abstract}
The nitrogen fertilization, in general, minimizes the effects of salinity on plants, but the mitigating action depends on plant species, cultivar, soil texture and plant age, among other factors. The objective of this study was to evaluate the effects of irrigation water salinity and nitrogen fertilization on maize physiology and growth (Zea mays) in soils with different textures. The experiment was carried out in a greenhouse in Fortaleza City, CE, Brazil, in PVC soil columns $(100 \times 20 \mathrm{~cm})$. The design was completely randomized using the factorial $2 \times 2 \times 4$, referring to two soils, an Ultisol and a Quartzipsamment, nitrogen doses of 105 and $210 \mathrm{~kg} \mathrm{ha}^{-1}$, under irrigation with saline water of $0.5,2.0,4.0$ and $6.0 \mathrm{dS} \mathrm{m}^{-1}$, with four repetitions. With the exception of stem diameter, salinity of water impaired plant growth and leaf gas exchanges. The Ultisol provided better growth and physiological responses compared to the Quartzipsamment. The nitrogen doses did not mitigate growth variables except root biomass. The gas exchanges increased with the highest nitrogen dose, without interaction with the salinity.
\end{abstract}

Key words: Zea mays, leaf gas exchange, soil texture

\section{Crescimento e fisiologia do milho sob salinidade da água e adubação nitrogenada em dois solos}

RESUMO: A adubação nitrogenada, em geral, minimiza os efeitos da salinidade às plantas, mas a ação mitigadora depende da espécie vegetal, cultivar, textura do solo e idade das plantas, entre outros fatores. Assim, objetivou-se avaliar os efeitos da salinidade da água de irrigação e adubação nitrogenada na fisiologia e crescimento do milho (Zea mays) em solos com texturas diferentes. O experimento foi realizado em casa de vegetação em Fortaleza, CE, utilizando-se colunas de solo de policloreto de vinila - PVC $(100 \times 20 \mathrm{~cm})$. O delineamento foi inteiramente casualizado usando o fatorial $2 \times 2 \times 4$, referente a dois solos, um Argissolo Vermelho-Amarelo e um Neossolo Quartzarênico, doses de nitrogênio de 105 e $210 \mathrm{~kg} \mathrm{ha}^{-1}$, sob irrigação com águas de salinidade $0,5,2,0,4,0$ e 6,0 dS m$~^{-1}$, com quatro repetições. Com exceção do diâmetro do caule, a salinidade da água prejudicou o crescimento e as trocas gasosas foliares das plantas. O Argissolo proporcionou melhores respostas no crescimento e fisiologia em comparação ao Neossolo. As doses de nitrogênio não mitigaram as variáveis de crescimento, exceto a biomassa radicular. As trocas gasosas aumentaram com a maior dose de nitrogênio, sem interação com a salinidade.

Palavras-chave: Zea mays, trocas gasosas foliares, textura do solo 


\section{INTRODUCTION}

Plant growth and development are results of genetic factors, environmental factors and their interactions, and their quantification makes it possible to improve agricultural production (Oliveira et al., 2010). Among the environmental factors which inhibit the development of agricultural crops, the excess of salts in soil or in the irrigation water stands out (Guimarães et al., 2013; Azevedo et al., 2017).

Salinity inhibits plant growth due to osmotic effects, toxic effects and damage to the absorption of essential nutrients. It also cause negative effects on gas exchanges as a result of the reduction in available water caused by decrease in the osmotic potential of the soil solution (Andrade et al., 2018).

The response of plants to salinity is complex, and physiological, biochemical and molecular adjustment mechanisms are necessary for their survival in saline environments (Willadino et al., 2017). The efficiency of these mechanisms depends on the species, genotype or cultivar, concentration and composition of salts in the irrigation water or soil solution.

Research studies point to the increase in nitrogen $(\mathrm{N})$ supply as a management strategy capable of minimizing the effects of salinity on plants (Oliveira et al., 2014). This action results in greater accumulation of organic compounds containing N such as proline (Perveen \& Nazir, 2018), which can increase the capacity for cellular osmotic adjustment, increasing the tolerance to water and salt stresses. However, salinity may interfere in the acquisition and utilization of $\mathrm{N}$ (Feijão et al., 2013) and soil physical properties may affect its availability to plants (Stevenson, 1982; Luizão et al., 2004).

Considering that water and/or soil salinity compromises the morphophysiological attributes of plants and that $\mathrm{N}$ attenuates salinity-induced damage, the objective was to evaluate the effects of irrigation using water with increasing salinity levels on the growth and physiology of the doublehybrid maize 'BRS 2020' in soils of different textures.

\section{Material ANd Methods}

The study was carried out in a greenhouse at the Federal University of Ceará (UFC), in Fortaleza, CE, Brazil ( $03^{\circ} 45^{\prime} \mathrm{S}$; $38^{\circ} 33^{\prime} \mathrm{W}$ ), at $19 \mathrm{~m}$ of altitude, in the period from April 5 to June 11, 2016. Data of temperature, air relative humidity and light intensity inside the greenhouse during the experimental period were obtained from a data logger $\left(\mathrm{HOBO}^{\oplus} \mathrm{U} 12-012\right.$ Temp/RH/Light/Ext model) programmed to record data every $15 \mathrm{~min}$. The average daily temperature ranged from
25.8 to $31.6{ }^{\circ} \mathrm{C}$; air relative humidity from 64.1 to $91.8 \%$ and light intensity (between 6 and $18 \mathrm{~h}$ ) from 5,231 to 18,535 Lux.

Materials of the soils Ultisol and Quartzipsament were collected in the layers of 0-20, 21-60, 61-100 (Ultisol) and 0-20 and 21-100 cm (Quartzipsament), which correspond to their pedogenetic horizons, were used as substrate, following the same sequence found in the field to fill the columns. Both soils were collected and separated according to their horizons, pounded to break up clods, sieved through 5-mm mesh and characterized with respect to their physical and chemical attributes (Table 1).

Particle-size analysis was performed by the pipette method, soil bulk density by volumetric ring method, particle density by the volumetric flask method, electrical conductivity was measured in saturated paste extract and $\mathrm{pH}$ in water.

The experimental design was completely randomized in a $2 \times 2 \times 4$ factorial arrangement, corresponding to two soils (Ultisol and Quartzipsamment), two $\mathrm{N}$ doses $\left(210\right.$ and $\left.105 \mathrm{~kg} \mathrm{ha}^{-1}\right)$ and four levels of irrigation water salinity $\left(0.5 ; 2.0 ; 4.0\right.$ and $\left.6.0 \mathrm{dS} \mathrm{m}^{-1}\right)$, with four repetitions.

The polyvinyl chloride (PVC) columns with dimensions of $100 \times 20 \mathrm{~cm}$, used to cultivate the plants, received an internal layer of glue and sand to improve the adhesion between the soil and the PVC, decreasing the preferential water flow. The base was closed with a PVC cap, which was perforated and attached to a tube to collect drained water. In the assembly, the sequence of soil horizons as they were in the field was followed, compacting them up to a density of $1.53 \mathrm{~kg} \mathrm{dm}^{-3}$. Sand was added to the column up to $10 \mathrm{~cm}$ height and the remainder was filled with the soils to be evaluated. For the Ultisol, the first layer $(20 \mathrm{~cm})$ corresponded to the A horizon, the second $(25 \mathrm{~cm})$ to the E horizon and the third $(40 \mathrm{~cm})$ to the textural B horizon. For the Quartzipsamment, the first layer $(20 \mathrm{~cm})$ was formed by the A horizon and the second $(65 \mathrm{~cm})$ by the $\mathrm{C}$ horizon.

Three seeds of the double-hybrid maize 'BRS 2020' were sown in each column, with thinning performed 10 days after sowing and leaving one plant per column. After thinning, saline waters began to be applied through daily irrigation, maintaining a leaching fraction of 0.15 . Low-salinity water was obtained by diluting well water (EC of $1.0 \mathrm{dS} \mathrm{m}^{-1}$ ) in distilled water until reaching $\mathrm{EC}_{\mathrm{w}}$ of $0.5 \mathrm{dS} \mathrm{m}^{-1}$, which was measured using a portable conductivity meter. The other saline levels of irrigation water were obtained by adding $\mathrm{NaCl}$ and $\mathrm{CaCl}_{2} \cdot 2 \mathrm{H}_{2} \mathrm{O}$ at equivalent proportion of $7: 3$, respectively.

Fertilization with 2.62 and $1.31 \mathrm{~g}$ of $\mathrm{N}$ per soil column in the form of urea and $1 \mathrm{~g}$ of $\mathrm{K}$ per column was divided into

Table 1. Physical and chemical characterization of the soils used in the experiment, according to the profile depth

\begin{tabular}{|c|c|c|c|c|c|c|c|c|c|c|c|c|c|c|}
\hline \multirow{2}{*}{$\begin{array}{l}\text { Soil layer } \\
\text { (cm) }\end{array}$} & Sand & Silite & Clay & \multirow{2}{*}{ Soil texture } & \multirow{2}{*}{$\begin{array}{c}\rho_{\mathrm{s}} \\
\left(\mathrm{kg} \mathrm{dm}^{-3}\right)\end{array}$} & \multirow{2}{*}{$\begin{array}{c}E C_{\mathrm{es}} \\
\left(\mathrm{dS} \mathrm{m}^{-1}\right)\end{array}$} & \multirow{2}{*}{ pH } & \multirow{2}{*}{$\begin{array}{c}P \\
\left(m g g^{-1}\right)\end{array}$} & $\mathrm{Ca}$ & $\mathrm{Mg}$ & $\mathrm{Na}$ & K & C & $\mathrm{N}$ \\
\hline & \multicolumn{3}{|c|}{$\left(\mathrm{g} \mathrm{kg}^{-1}\right)$} & & & & & & \multicolumn{4}{|c|}{$\left(\mathrm{cmol}_{\mathrm{c}} \mathrm{kg}^{-1}\right)$} & \multicolumn{2}{|c|}{$\left(g_{k g}^{-1}\right)$} \\
\hline & & & & & & \multicolumn{3}{|l|}{ Ultisol } & & & & & & \\
\hline $0-20$ & 825 & 107 & 68 & Sandy Ioam soil & 1.47 & 0.12 & 6.3 & 33 & 1.90 & 0.30 & 0.16 & 0.43 & 12.3 & 1.24 \\
\hline $21-60$ & 845 & 85 & 70 & Sandy loam soil & 1.46 & 0.10 & 6.2 & 8 & 0.70 & 0.50 & 0.17 & 0.24 & 7.32 & 0.75 \\
\hline $61-100$ & 527 & 157 & 316 & Clay loam soil & 1.35 & 0.11 & 5.7 & 5 & 1.10 & 0.60 & 0.18 & 0.90 & 3.36 & 0.35 \\
\hline \multicolumn{15}{|c|}{ Quartzipsamment } \\
\hline $0-20$ & 923 & 53 & 24 & Sandy soil & 1.54 & 0.36 & 5.3 & 2 & 0.90 & 0.60 & 0.21 & 0.59 & 7.56 & 0.77 \\
\hline $21-100$ & 929 & 42 & 29 & Sandy soil & 1.55 & 0.46 & 5.4 & 2 & 0.50 & 0.40 & 0.28 & 0.67 & 2.16 & 0.22 \\
\hline
\end{tabular}

$\rho_{\mathrm{s}}-$ Soil bulk density; $\mathrm{EC}_{\mathrm{es}}-$ Electrical conductivity of the substrate 
four applications: $15 \%$ at 10 days after sowing (DAS), $25 \%$ at $25 \mathrm{DAS}, 25 \%$ at $40 \mathrm{DAS}$ and $35 \%$ applied at 55 DAS. At sowing, each column received $1.12 \mathrm{~g}$ of $\mathrm{P}$ and $1 \mathrm{~g}$ of the FTE BR 12 mix, containing Ca (7.1\%), S (5.7\%), B (1.8\%), Cu (0.8\%), Mn (2.0\%), Mo (0.1\%) and Zn (9.0\%). Magnesium was supplied as magnesium sulfate through irrigation water.

At 67 days after sowing, the following variables were evaluated: growth in height, stem diameter at the base of the plant, leaf area using a leaf area integrator, dry biomass of roots, dry biomass of stem + sheaths, dry biomass of leaf blades and total dry biomass. Measurements of stomatal conductance (gs), photosynthesis (A), transpiration (E) and internal $\mathrm{CO}_{2}$ concentration $(\mathrm{Ci})$ were performed at 15,30 , 45 and 60 days after the treatments began, in the first fully expanded leaf, from 8:00 to 10:30 a.m., using a portable infrared gas analyzer (LI6400XT model, Licor, USA) under saturating light of $1,800 \mu \mathrm{mol} \mathrm{m} \mathrm{m}^{-2} \mathrm{~s}^{-1}$ and ambient conditions of temperature and $\mathrm{CO}_{2}$ concentration.

The data were subjected to the Kolmogorov-Smirnov normality test, as a prerequisite for analysis of variance by $\mathrm{F}$ test. Means referring to soils and $\mathrm{N}$ doses were compared by F test, which is conclusive for factors with two levels, whereas those referring to water salinity were compared by regression using the program Assistat version 7.7 (Silva \& Azevedo, 2016).

\section{Results AND Discussion}

Except for root dry biomass, the interaction between water salinity, $\mathrm{N}$ and soil type did not interfere significantly in any of the variables evaluated and the interaction between soil and water salinity caused significant effects only on root dry biomass (RDB) and total dry biomass (TDB) (Table 2).

The Ultisol resulted in higher growth and biomass production of the plants than the Quartzipsament, with superiority of $22.78,12.58,32.38,45.94,36.47,38.91$ and $41.03 \%$, respectively for the growth in height, stem diameter, leaf area, dry biomass of roots, stem + sheaths, leaves and total dry biomass (Table 2). This superiority of the Ultisol over the Quartzipsament can be a response to the lower sand proportion and higher availability of nutrients (Table 1 ), especially potassium, which performs osmoregulatory function in plants under salt stress, providing better conditions for root and shoot growth of plants in general, including maize.

Additionally, the higher clay proportion of the Ultisol possibily promote higher aggregation and contribute to aggregate stability, resulting in greater soil porosity for water storage, water dynamics and nutrients for plant growth (Wang et al., 2017). Similar responses have been obtained by Santos et al. (2017) for stem height and diameter in soybean, Fraga Júnior et al. (2012) for leaf area in citrus and by Braccini et al. (1999) for dry biomass in maize, all with higher results in clayey soils compared to soils with lower clay content.

In relation to $\mathrm{N}$ fertilization, significance was only observed on $\mathrm{RDB}$, in which the dose of $210 \mathrm{~kg} \mathrm{ha}^{-1}$ resulted in higher root biomass. The increase of $\mathrm{N}$ supply, in general, stimulates phytomass production, indicating that $\mathrm{N}$ can favor the processes of plant growth and development, due to higher carbon fixation (Martuscello et al., 2006). In addition, roots have faster osmotic adjustment and slower loss of turgor than the shoots (Oliveira et al., 2016). Similar responses in maize also showed that $\mathrm{N}$ fertilization promoted increase in $\mathrm{RDB}$ (Morais et al., 2015).

Compared to the control treatment $\left(0.5 \mathrm{dS} \mathrm{m} \mathrm{m}^{-1}\right), \mathrm{PH}$ decreased by $28.65 \%$ as a function of the increase in irrigation water salinity up to the level of $6.0 \mathrm{dS} \mathrm{m}^{-1}$ (Figure 1A). Soil salinity limits plant growth due to excess of salts in the root zone, causing a greater osmotic effect outside the roots and restricting the water flow from the soil to the plants (Lima et al., 2014). With the increase in the osmotic pressure of the medium, there is a reduction in the readily available water, affecting cell division and elongation (Taiz et al., 2017). The decrease of $\mathrm{PH}$ in maize has also been documented by Gomes et al. (2011) and Souza et al. (2014) using irrigation water with EC levels of 5.0 and $4.5 \mathrm{dS} \mathrm{m} \mathrm{m}^{-1}$, respectively.

Compared to the control, plants irrigated with $\mathrm{EC}_{\mathrm{w}}=6.0$ $\mathrm{dS} \mathrm{m}^{-1}$ had a $46.3 \%$ decrease in LA (Figure 1B). Plants under water and salt stresses have smaller LA, thus reducing the transpiration surface and water loss (Taiz et al., 2017). The reduction in LA also contributes to maintaining the balance between absorption and transpiration, which may have increased water use efficiency, reducing the accumulation of salts in the plant (Nobre et al., 2011). However, the reduction

Table 2. Summary of analysis of variance, by mean squares, for plant height (PH), stem diameter (SD), leaf area (LA), root dry biomass (RDB), dry biomass of stem + sheaths (SDB), dry biomass of leaf blades (LDB) and total dry biomass (TDB) of maize plants under water salinity and nitrogen fertilization in soils with different textures

\begin{tabular}{|c|c|c|c|c|c|c|c|}
\hline Treatments & $\mathrm{PH}$ & SD & LA & RDB & SDB & LDB & TDB \\
\hline Soil $(A)$ & $37.92^{\star \star}$ & $14.32^{\star \star}$ & $27.96^{\star \star}$ & $291.15^{* \star}$ & $40.43^{\star \star}$ & $52.65^{\star \star}$ & $101.64^{* x}$ \\
\hline $\mathrm{N}$ dose $(\mathrm{B})$ & $0.08^{\text {ns }}$ & $0.08^{\text {ns }}$ & $3.90^{\text {ns }}$ & $11.70^{* \star}$ & $0.06^{\text {ns }}$ & $2.11^{\mathrm{ns}}$ & $2.19^{\text {ns }}$ \\
\hline Salinity (C) & $26.26^{\star \star}$ & $2.64^{\text {ns }}$ & $23.12^{\star \star}$ & $703.98^{* *}$ & $40.70^{\star *}$ & $11.73^{\star \star}$ & $106.46^{* x}$ \\
\hline$A \times B$ & $0.003^{\text {ns }}$ & $2.05^{\mathrm{ns}}$ & $2.46^{\text {ns }}$ & $1.99^{\mathrm{ns}}$ & $2.25^{\mathrm{ns}}$ & $1.65^{\mathrm{ns}}$ & $2.13^{\text {ns }}$ \\
\hline$A \times C$ & $0.57^{\mathrm{ns}}$ & $1.24^{\text {ns }}$ & $1.92^{\text {ns }}$ & $31.53^{\star \star}$ & $1.60^{\text {ns }}$ & $1.50^{\text {ns }}$ & $2.97^{\star}$ \\
\hline$B \times C$ & $0.32^{\mathrm{ns}}$ & $0.70^{\text {ns }}$ & $0.57^{\mathrm{ns}}$ & $5.69^{* *}$ & $0.67^{\mathrm{ns}}$ & $0.49^{\text {ns }}$ & $1.19^{n s}$ \\
\hline$A \times B \times C$ & $0.98^{\text {ns }}$ & $1.03^{\text {ns }}$ & $1.63^{\text {ns }}$ & $3.12^{*}$ & $0.60^{\text {ns }}$ & $1.45^{\text {ns }}$ & $0.54^{\text {ns }}$ \\
\hline CV $(\%)$ & 13.29 & 12.28 & 21.08 & 8.76 & 19.40 & 17.95 & 13.51 \\
\hline & $\mathrm{cm}$ & mm & $\mathrm{cm}^{2}$ & g & g & g & g \\
\hline Ultisol & $204.8 \mathrm{a}$ & $17.0 \mathrm{a}$ & $3181.9 \mathrm{a}$ & $26.97 \mathrm{a}$ & $47.90 \mathrm{a}$ & $20.92 \mathrm{a}$ & $95.79 \mathrm{a}$ \\
\hline Quartzipsamment & $166.8 b$ & $15.1 b$ & 2403.6 b & $18.48 b$ & $35.10 \mathrm{~b}$ & $15.06 \mathrm{~b}$ & $67.92 \mathrm{~b}$ \\
\hline $210 \mathrm{~kg} \mathrm{ha}^{-1} \mathrm{~N}$ & $184.9 \mathrm{a}$ & $16.0 \mathrm{a}$ & $2938.2 \mathrm{a}$ & $23.57 \mathrm{a}$ & $41.74 \mathrm{a}$ & $18.57 \mathrm{a}$ & $83.90 \mathrm{a}$ \\
\hline $105 \mathrm{~kg} \mathrm{ha}^{-1} \mathrm{~N}$ & $186.7 \mathrm{a}$ & $16.1 \mathrm{a}$ & $2647.4 \mathrm{a}$ & $21.87 \mathrm{~b}$ & $41.25 \mathrm{a}$ & $18.57 \mathrm{a}$ & $79.81 \mathrm{a}$ \\
\hline
\end{tabular}

ns - Not significant; " and ** - Significant by F test, at p $\leq 0.05$ and p $\leq 0.01$, respectively; Means followed by the same letter in the column do not differ statistically by F test at $\mathrm{p} \leq 0.05$ 

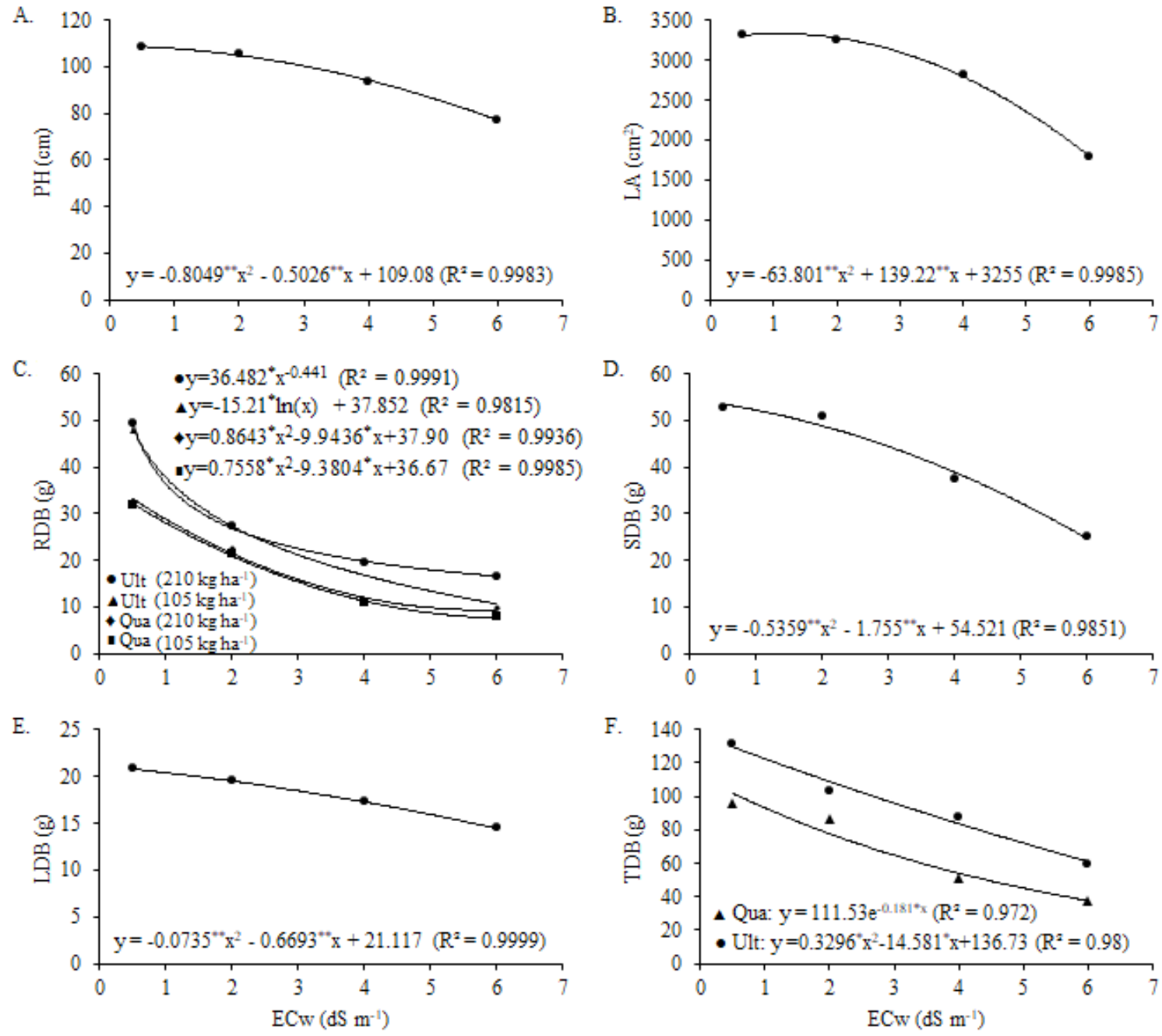

Ult - Ultisol; Qua - Quartzipsament; " and "* - Significant at $\mathrm{p} \leq 0.05$ and $\mathrm{p} \leq 0.01$, respectively, by F test

Figure 1. Plant height-PH (A), leaf area-LA (B), root dry biomass-RDB (C), dry biomass of stem + sheaths-SDB (D), dry biomass of leaf blades-LDB (E) and total dry biomass-TDB (F) of maize plants under salt stress in two soils

in the area for photosynthesis can cause yield losses. Similar results were observed in sweet corn and popcorn with LA reductions of 28.2 and $28.7 \%$, respectively, when irrigated using water with EC of $4.5 \mathrm{dS} \mathrm{m}^{-1}$, compared to $0.5 \mathrm{dS} \mathrm{m}^{-1}$ (Souza et al., 2014).

The root dry biomass (RDB) decreased in the Ultisol and Quartzipsament as the $\mathrm{EC}_{\mathrm{w}}$ increased, regardless of the applied $\mathrm{N}$ dose (Figure 1C). However, it is observed that in both soils this decrease was lower at the highest $\mathrm{N}$ dose, especially at the highest levels of salinity, indicating that $\mathrm{N}$ can reduce the effects of salinity on the reduction of root biomass.

The difference found in the root dry biomass content between the Ultisol and the Quartzipsament can be attributed to the fact that clay soils have a higher nitrogen retention capacity than sandy soils. In this case, a higher amount of $\mathrm{N}$ in the Ultisol may provide increased biomass production. Since $\mathrm{N}$ performs structural function, participating in organic compounds that are vital to plants, it plays the role of promoting growth and can inhibit the effects of salinity on plants. Melo et al. (2015) also observed lower losses in RDB due to $\mathrm{N}$ fertilization.

The increase in $\mathrm{EC}_{\mathrm{w}}$ caused losses of 52.14 and $30.45 \%$ in SDB (Figure 1D) and LDB (Figure 1E), respectively. The threshold water salinity for the maize crop is $1.1 \mathrm{dS} \mathrm{m} \mathrm{m}^{-1}$ (Ayers \& Westcot, 1999). Salinity levels above the threshold of the species or cultivar reduces growth due to increased metabolic energy spent on the absorption of water and nutrients and on osmotic adjustment, besides reducing crop growth and production (Rhoades, 2000). The ionic effect caused by the accumulation of ions in plant tissues also reduces plant growth (Munns \& Tester, 2008), affecting biomass production. Similar responses were found in popcorn, which showed a reduction in SDB and LDB as salinity increased (Oliveira et al., 2016).

There was a reduction in $\mathrm{TDB}$ as the $\mathrm{EC}_{\mathrm{w}}$ increased, with losses of 54.45 and $60.72 \%$ in the Ultisol and Quartzipsament, respectively (Figure 1F). The smaller loss of TDB in the Ultisol suggests that, even under salinity conditions, the more clayey texture of the Ultisol provides greater capacity of water and nutrient retention, increasing the availability of both to the plant. The high concentration of salts in the irrigation water can lead to break in water potential homeostasis, ionic imbalance at the soil-plant interface and cause toxicity in the plant, altering its growth and dry matter production (Asch et al., 2000). Sousa et al. (2012) also reported that maize TDB decreased with the use of irrigation water with $\mathrm{EC}_{\mathrm{w}}=3.4 \mathrm{dS} \mathrm{m}^{-1}$.

The soil type was significant for gs, A, E and Ci and the $\mathrm{N}$ doses were significant for gs, A and E (Table 3 ). The salinity 
Table 3. Summary of ANOVA and means for stomatal conductance (gs), transpiration (E), photosynthesis (A), and internal $\mathrm{CO}_{2}$ concentration $(\mathrm{Ci})$ in maize plants under salt stress and nitrogen doses in two soils

\begin{tabular}{|c|c|c|c|c|}
\hline SV & gs & E & A & Ci \\
\hline Soil $(A)$ & $52.95^{\star *}$ & $5.39^{*}$ & $9.80^{* \star}$ & $4.95^{*}$ \\
\hline $\mathrm{N}$ dose (B) & $9.65^{\star *}$ & $4.67^{*}$ & $15.33^{* *}$ & $1.59^{\text {ns }}$ \\
\hline Salinity (C) & $113.33^{* *}$ & $18.39^{* *}$ & $34.60^{* *}$ & $20.09^{* *}$ \\
\hline$A \times B$ & $0.49^{n s}$ & $3.12^{\text {ns }}$ & $5.87^{\star}$ & $1.57^{\mathrm{ns}}$ \\
\hline$A \times C$ & $8.01^{* *}$ & $0.62^{\text {ns }}$ & $0.08^{\text {ns }}$ & $2.10^{\text {ns }}$ \\
\hline$B \times C$ & $1.16^{\mathrm{ns}}$ & $1.44^{\mathrm{ns}}$ & $1.22^{\text {ns }}$ & $2.21^{\text {ns }}$ \\
\hline$A \times B \times C$ & $2.59^{\text {ns }}$ & $1.24^{\text {ns }}$ & $2.30^{\text {ns }}$ & $1.14^{\mathrm{ns}}$ \\
\hline CV (\%) & 7.75 & 13.29 & 9.23 & 27.44 \\
\hline & $\mathrm{mol} \mathrm{m}^{2} \mathrm{~s}^{-1}$ & 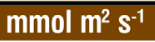 & \multicolumn{2}{|c|}{$\mu \mathrm{mol} \mathrm{m}^{2} \mathrm{~s}^{-1}$} \\
\hline Ultisol & $0.22 \mathrm{a}$ & $6.19 \mathrm{a}$ & $34.52 \mathrm{a}$ & $64.57 \mathrm{a}$ \\
\hline Quartzipsament & $0.19 b$ & $5.73 b$ & $32.11 \mathrm{~b}$ & $55.41 \mathrm{~b}$ \\
\hline $210 \mathrm{~kg} \mathrm{ha}^{-1} \mathrm{~N}$ & $0.21 \mathrm{a}$ & $6.18 \mathrm{a}$ & $34.82 \mathrm{a}$ & $57.39 \mathrm{a}$ \\
\hline $105 \mathrm{~kg} \mathrm{ha}^{-1} \mathrm{~N}$ & $0.20 \mathrm{~b}$ & $5.75 \mathrm{~b}$ & $31.81 \mathrm{~b}$ & $62.59 \mathrm{a}$ \\
\hline
\end{tabular}

SV - Source of variation; ${ }^{\text {ns }}$ - Not significant, " and "* - Significant by F test, at $\mathrm{p} \leq 0.05$ and $\mathrm{p} \leq 0.01$, respectively; Means followed by the same letter for the same soil or $\mathrm{N}$ dose in the column do not differ statistically by $\mathrm{F}$ test at $\mathrm{p} \leq 0.05$

levels significantly influenced all variables. There were also significant interactions of 'soils $\mathrm{x}$ doses' for $\mathrm{A}$ and 'soil $\mathrm{x}$ salinity' for gs.

Plants cultivated in the Ultisol, compared to the Quartzipsament, showed higher values of gs, A, E and Ci with successive increments of $15.79,8.03,7.51$ and $16.53 \%$ (Table 3), which could possibly be attributed to the fact that the Ultisol has more nutrients, promoting better development of both shoots and root system, whereas the highest $\mathrm{N}$ dose led to increments in gs, $\mathrm{A}$ and $\mathrm{E}$. However, there was no effect of $\mathrm{N}$ doses on $\mathrm{Ci}$. Since $\mathrm{N}$ is part of the main components of the photosynthetic system, the increase in its availability generally results in positive effects on the carbon assimilation rate (Correia et al., 2005).

The interaction between soils and $\mathrm{N}$ doses affected photosynthesis (Figure 2). For the dose of $210 \mathrm{~kg} \mathrm{ha}^{-1}$, the highest photosynthetic rates were found in the Ultisol, showing
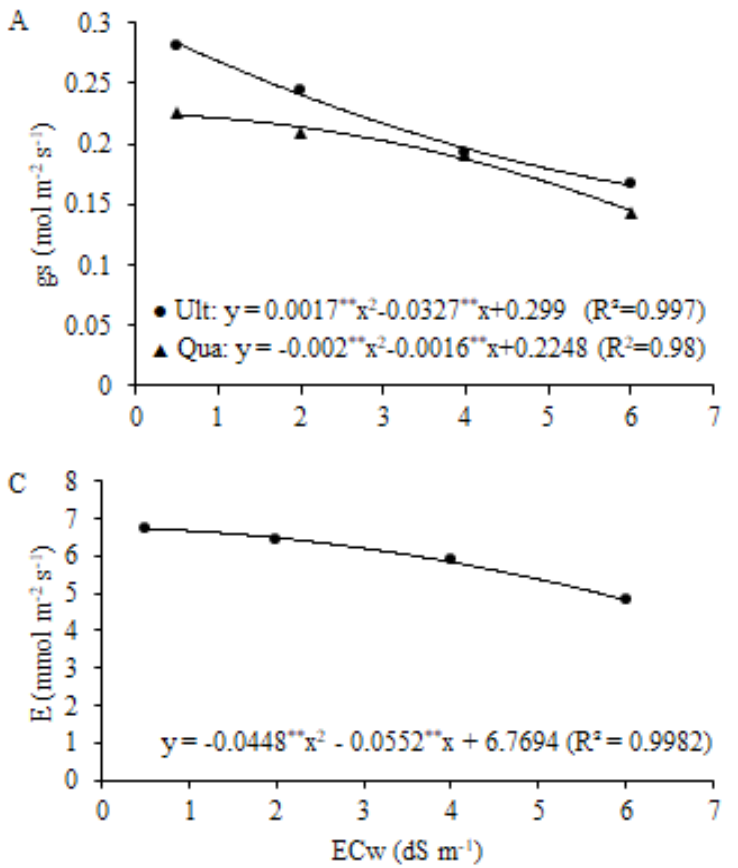

Ult - Ultisol; Qua - Quartzipsament; ${ }^{* *}$ - Significant at $\mathrm{p} \leq 0.01$ by F test

Figure 3. Stomatal conductance-gs (A), net photosynthesis-A (B), transpiration-E (C) and internal CO $\mathrm{CO}_{2}$ contration-Ci (D) of maize plants as a function of irrigation water electrical conductivity $\left(\mathrm{EC}_{\mathrm{w}}\right)$

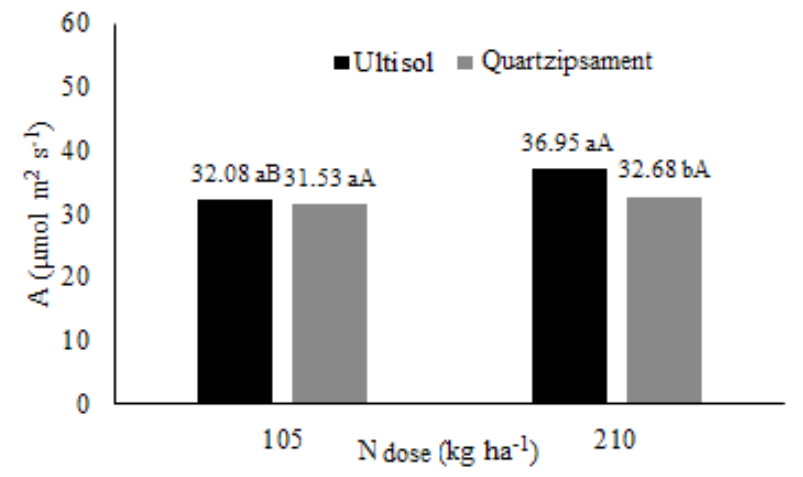

Means followed by the same letter do not differ statistically by $\mathrm{F}$ test at $\mathrm{p} \leq 0.05$; The lowercase letters compare the soils in each $\mathrm{N}$ dose and the uppercase letter the $\mathrm{N}$ doses in each soil

Figure 2. Photosynthesis (A) in maize plants under salt stress and nitrogen fertilization in two soils

greater utilization of $\mathrm{N}$ in this soil, especially due to its better structuring, water retention and nutrient adsorption. However, there was no interaction between the dose of $105 \mathrm{~kg} \mathrm{ha}^{-1}$ and the two soils, or between both $\mathrm{N}$ doses and Quartzipsament.

In comparison to the control, the losses of gs in plants

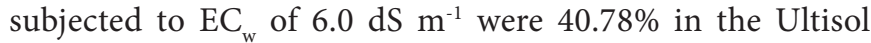
and $36.43 \%$ in the Quartzipsament (Figure 3A). However, it is worth pointing out that, although plants cultivated in the Ultisol had the highest losses of gs, this soil led to higher values of gs compared to the Quartzipsament. Stomatal closure is one of the first responses of the plant to stress in order to avoid excessive water loss (Gomes et al., 2011) and occurs due to the decrease of water flow in the plant as a result of the high concentration of salts in the root zone. The reduction in the osmotic potential of the soil solution decreases water availability to plants and causes a water stress that consequently leads to stomatal closure. Sousa et al. (2016) also verified, in the maize crop, that irrigation with saline waters causes reduction in gs.
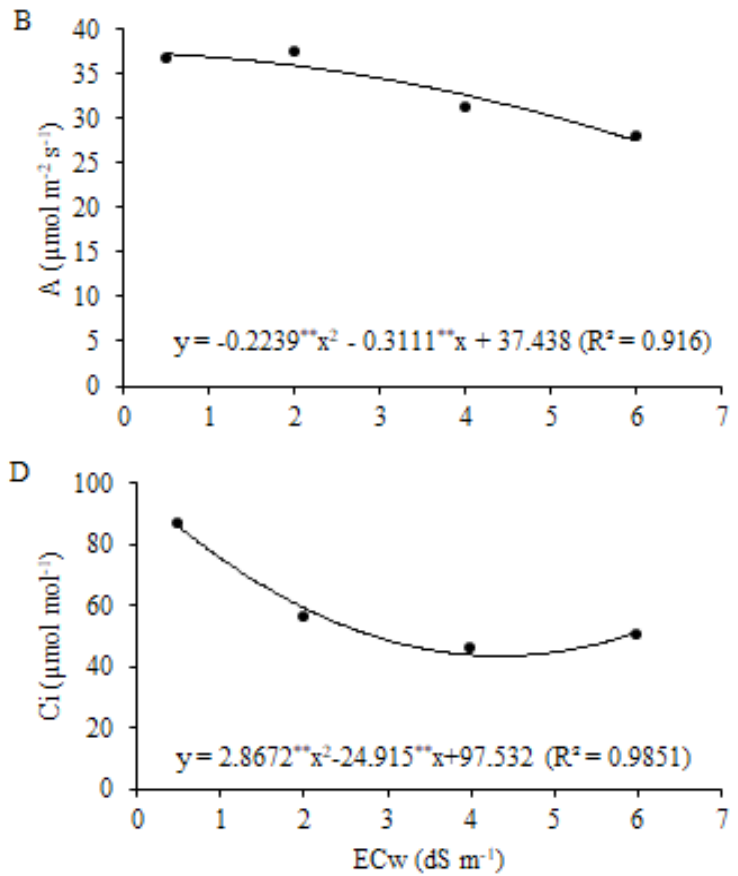
Photosynthesis was reduced by $23.53 \%$ in plants irrigated with $\mathrm{EC}_{\mathrm{w}}=6.0 \mathrm{dS} \mathrm{m} \mathrm{m}^{-1}$, compared to the control plants. Photosynthesis is one of the main physiological processes affected by salinity and can be inhibited by the accumulation of $\mathrm{Na}^{+}$and/or $\mathrm{Cl}^{-}$ions in chloroplasts, which affect the biochemical and photochemical processes involved in photosynthesis (Taiz et al., 2017). Additionally, the water deficit induced by salinity tends to cause stomatal closure, which results in limitation in $\mathrm{Ci}$ and may also affect the concentration of the pigments involved in photosynthesis. With the reduction in gs, the availability of $\mathrm{CO}_{2}$ to the leaves decreases (Gomes et al., 2011), causing a reduction in the net photosynthesis due to the decrease in the partial pressure of $\mathrm{CO}_{2}$ in the intercellular spaces or in the substomatal chamber (Amorim et al., 2010). Results similar to the present study were obtained by Silva et al. (2013), who found that the increase in irrigation water salinity reduced photosynthesis in cowpea.

The increase in salinity also reduced E, causing losses of $28.67 \%$ when plants were subjected to the maximum $\mathrm{EC}_{\mathrm{w}}$ (Figure 3C). Plants under salt stress generally show a reduction in the water flow to the shoots, due to the decrease in gs, reducing the flow of water vapor to the atmosphere (Gonçalves et al., 2010). Sousa et al. (2016) also reported that $\mathrm{E}$ was reduced by salinity in maize.

The $\mathrm{CO}_{2}$ concentration $(\mathrm{Ci})$ decreased as the irrigation water salinity increased to $4.0 \mathrm{dS} \mathrm{m} \mathrm{m}^{-1}$, with a reduction of $46.95 \%$ compared to the control (Figure 3D). Subsequently,

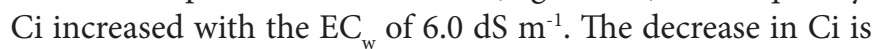
related to lower gs, because the increase in the concentration of salts in soil reduces the osmotic potential of its solution, causing water stress and leading to stomatal closure, which results in a limitation of $\mathrm{Ci}$. Thus, stomatal closure usually reduces gs, $\mathrm{Ci}$ and $\mathrm{CO}_{2}$ assimilation rate (Musyimi et al., 2007). However, the subsequent increase in $\mathrm{Ci}$ with the highest salinity level points to a non-stomatal effect on photosynthesis, indicating a more severe stress condition for maize plants.

\section{Conclusions}

1. The nitrogen doses did not attenuate the effects of salinity on maize plants.

2. Although root biomass increased with the additional nitrogen fertilization, there were different effects depending on the class of soil.

\section{ACKNOWLEDgments}

Acknowledgments are due to the Instituto Nacional de Ciência e Tecnologia em Salinidade (INCTSal), Coordenação de Aperfeiçoamento de Pessoal de Nível Superior (CAPES) and Conselho Nacional de Desenvolvimento Científico e Tecnológico (CNPq) for financial support provided.

\section{Literature Cited}

Amorim, A. V.; Gomes Filho, E.; Bezerra, M. A.; Prisco, J. T.; Lacerda, C. F. de. Respostas fisiológicas de plantas adultas de cajueiro anão precoce à salinidade. Revista Ciência Agronômica, v.41, p.113-121, 2010.
Andrade, J. R. de; Maia Júnior, S. de O.; Silva, R. F. B. da; Barbosa, J. W. da S.; Nascimento, R. do; Alencar, A. E. V. de. Trocas gasosas em genótipos de feijão-caupi irrigados com água salina. Revista Brasileira de Agricultura Irrigada, v.12, p.2653-2660, 2018. https://doi.org/10.7127/RBAI.V12N300829

Asch, F.; Dingkuhn, M.; Dorffing, K. Salinity increases $\mathrm{CO}_{2}$ assimilation but reduces growth in field grown irrigated rice. Plant and Soil, v.218, p.1-10, 2000. https://doi. org/10.1023/A:1014953504021

Ayers, R. S.; Westcot, D. W. A qualidade da água na agricultura. 2.ed. Campina Grande: UFPB, 1999. 153p. Estudos FAO, Irrigação e Drenagem, 29

Azevedo, P. R. L.; Bezerra, D. E. L.; Souto, F. M.; Bitu, S. G.; Pereira Junior, E. B. Efeito dos sais e da qualidade da água no solo e na planta. Revista de Agroecologia no Semiárido, v.1, p.1-12, 2017.

Braccini, M. do C. L.; Braccini, A. de L. e; Folini, J. M.; Silva, J. R. T. da. Produção de biomassa seca e teor de nutrientes do milho em resposta a doses e localização de osmocote em amostras de Latossolo Vermelho-escuro e areia quartzosa. Acta Scientiarum. Agronomy, v.21, p.497-503, 1999.

Correia, C. M.; Pereira, J. M. M.; Coutinho, J. F.; Björn, L. O.; Pereira, J. M. G. T. Ultraviolet-B radiation and nitrogen affect the photosynthesis of maize: A Mediterranean field study. European Journal of Agronomy, v.22, p.337-347, 2005. https:// doi.org/10.1016/j.eja.2004.05.002

Feijão, A. R.; Marques, E. C.; Silva, J. C. B. da; Lacerda, C. F. de; Prisco, J. T.; Gomes Filho, E. Nitrato modula os teores de cloreto e compostos nitrogenados em plantas de milho submetidas à salinidade. Bragantia, v.72, p.10-19, 2013. https://doi. org/10.1590/S0006-87052013005000021

Fraga Júnior, E. F.; Mauri, R.; Leal, D. P. V.; Barbosa, F. da S.; Vellame, L. M.; Coelho, R. D. Área foliar de citrus irrigado por gotejamento sob estresse hídrico contínuo e intermitente. Irriga, v.1, p.83-96, 2012. https://doi.org/10.15809/irriga.2012v1n01p83

Gomes, K. R.; Amorim, A. V.; Ferreira, F. J.; Andrade Filho, F. L.; Lacerda, C. F. de; Gomes Filho, E. Respostas de crescimento e fisiologia do milho submetido a estresse salino com diferentes espaçamentos de cultivo. Revista Brasileira de Engenharia Agrícola e Ambiental, v.15, p.365-370, 2011. https://doi. org/10.1590/S1415-43662011000400006

Gonçalves, E. R.; Ferreira, V. M.; Silva, J. V.; Endres, L.; Barbosa, T. P.; Duarte, W. de G. Trocas gasosas e fluorescência da clorofila a em variedades de cana-de-açúcar submetidas à deficiência hídrica. Revista Brasileira de Engenharia Agrícola e Ambiental, v.14, p.378-386, 2010. https://doi.org/10.1590/ S1415-43662010000400006

Guimarães, I. P.; Oliveira, F. N. de; Vieira, F. E. R.; Torres, S. B. Efeito da salinidade da água de irrigação na emergência e crescimento inicial de plântulas de mulungu. Revista Brasileira de Ciências Agrárias, v.8, p.137-142, 2013. https://doi.org/10.5039/agraria.v8i1a2360

Lima, G. S. de; Nobre, R. G.; Gheyi, H. R.; Soares, L. A. dos A.; Silva, A. O. da. Crescimento e componentes de produção da mamoneira sob estresse salino e adubação nitrogenada. Engenharia Agrícola, v.34, p.854-866, 2014. https://doi.org/10.1590/S010069162014000500005

Luizão, R. C.; Luizão, F. J.; Paiva, R. Q.; Monteiro, T. F.; Sousa, L. S.; Kruijt, B. Variation of carbon and nitrogen cycling processes along a topographic gradient in a central Amazonian forest. Global Change Biology, v.10, p.592-600, 2004. https://doi. org/10.1111/j.1529-8817.2003.00757.x 
Martuscello, J. A.; Fonseca, D. M. da; Nascimento Júnior, D. do; Santos, P. M.; Cunha, D. de N. F. V. da; Moreira, L. de M. Características morfogênicas e estruturais de capim-massai submetido a adubação nitrogenada e desfolhação. Revista Brasileira de Zootecnia, v.35, p.665-671, 2006. https://doi. org/10.1590/S1516-35982006000300006

Melo, N. C.; Fernandes, A. R.; Galvão, J. R. Crescimento e eficiência nutricional do nitrogênio em cultivares de milheto forrageiro na Amazônia. Revista Caatinga, v.28, p.68-78, 2015. https://doi. org/10.1590/1983-21252015v28n308rc

Morais, T. P. de; Brito, C. H. de; Ferreira, A. de S.; Luz, J. M. Q. Aspectos morfofisiológicos de plantas de milho e bioquímico do solo em resposta à adubação nitrogenada e à inoculação com Azospirillum brasilense. Revista Ceres, v.62, p.589-596, 2015. https://doi.org/10.1590/0034-737X201562060012

Munns, R.; Tester, M. Mechanisms of salinity tolerance. Annual Review of Plant Biology, v.59, p.651-681, 2008. https://doi. org/10.1146/annurev.arplant.59.032607.092911

Musyimi, D. M.; Netondo, G. W.; Ouma, G. Effects of salinity on gas exchange and nutrient uptake in avocados. Journal of Biological Sciences, v.7, p.496-505, 2007. https://doi.org/10.3923/ jbs.2007.496.505

Nobre, R. G.; Gheyi, H. R.; Soares, F. A. L.; Cardoso, J. A. F. Produção do girassol sob estresse salino e adubação nitrogenada. Revista Brasileira de Ciência do Solo, v.35, p.929-937, 2011. https://doi. org/10.1590/S0100-06832011000300027

Oliveira, F. de A. de; Medeiros, J. F. de; Alves, R. de C.; Linhares, P. S. F.; Medeiros, A. M. A. de; Oliveira, M. K. T. de. Interação entre salinidade da água de irrigação e adubação nitrogenada na cultura da berinjela. Revista Brasileira de Engenharia Agrícola e Ambiental, v.18, p.480-486, 2014. https://doi.org/10.1590/ S1415-43662014000500003

Oliveira, F. de A. de; Medeiros, J. F. de; Cunha, R. C. da; Souza, M. W. de L.; Lima, L. A. Uso de bioestimulante como agente amenizador do estresse salino na cultura do milho pipoca. Revista Ciência Agronômica, v.47, p.307-315, 2016.

Oliveira, F. de A. de; Oliveira, F. R. A. de; Campos, M. de S.; Oliveira, M. K. T. de; Medeiros, J. F. de; Silva, O. M. dos P. da. Interação entre salinidade e fontes de nitrogênio no desenvolvimento inicial da cultura do girassol. Revista Brasileira de Ciências Agrárias, v.5, p.479-484, 2010. https://doi.org/10.5039/agraria.v5i4a806

Perveen, S.; Nazir, M. Proline treatment induces salt stress tolerance in maize (Zea Mays L. CV. Safaid Afgoi). Pakistan Journal of Botany, v.50, p.1265-1271, 2018.

Rhoades, J. P. Uso de águas salinas para a produção agrícola. Campina Grande: UFPB, 2000. 117p.
Santos, T. D. dos; Meert, L.; Borghi, W. A.; Silva, P. S. da; Figueiredo, A. S. T. Desenvolvimento inicial de plantas de soja e qualidade de semeadura em função da velocidade de deslocamento da semeadora e textura do solo. Brazilian Journal of Applied Technology for Agricultural Science, v.10, p.97-103, 2017. https://doi.org/10.5935/PAeT.V10.N2.10

Silva, F. de A. S. e; Azevedo, C. A. V. de. The Assistat Software Version 7.7 and its use in the analysis of experimental data. African Journal of Agricultural Research, v.11, p.3733-3740, 2016. https://doi.org/10.5897/AJAR2016.11522

Silva, F. L. B. da; Lacerda, C. F. de; Neves, A. L. R.; Sousa, G. G. de; Sousa, C. H. C. de; Ferreira, F. J. Irrigação com águas salinas e uso de biofertilizante bovino nas trocas gasosas e produtividade de feijão-de-corda. Irriga, v.18, p.304-317, 2013. https://doi. org/10.15809/irriga.2013v18n2p304

Sousa, G. G. de; Marinho, A. B.; Albuquerque, A. H. P.; Viana, T. V. de A.; Azevedo, B. M. de. Crescimento inicial do milho sob diferentes concentrações de biofertilizante bovino irrigado com águas salinas. Revista Ciência Agronômica, v.43, p.237-245, 2012. https://doi.org/10.1590/S1806-66902012000200005

Sousa, G. G. de; Viana, T. V. de A.; Silva, G. L. da; Dias, C. N.; Azevedo, B. M. de. Interação entre salinidade e biofertilizante de caranguejo na cultura do milho. Magistra, v.28, p.44-53, 2016.

Souza, M. W. de L.; Cunha, R. C. da; Costa, P. A. de A.; Moura, I. N. B. M. de; Bezerra, F. M. S.; Lima, L. A.; Pereira, L. A. F.; Oliveira, F. de A. de. Desenvolvimento inicial de milho doce e milho pipoca sob estresse salino. Agropecuária Científica no Semiárido, v.10, p.65-72, 2014.

Stevenson, F. J. Origin and distribution of nitrogen in soil. In: Stevenson, F. J.; Bremner, J. M.; Hauck, R. D.; Keeney, D. R. (eds.). Nitrogen in agricultural soils. Madison: American Society of Agronomy, 1982. Cap.1, p.1-39. https://doi.org/10.2134/ agronmonogr22.c1

Taiz, L.; Zeiger, E.; Møller, I. M.; Murphy, A. Fisiologia e desenvolvimento vegetal. 6.ed. Porto Alegre: Artmed, 2017. $888 \mathrm{p}$.

Wang, L.; Li, X. G.; Lv, J.; Fu, T.; Ma, Q.; Song, W.; Wang, Y. P.; Li, F. M. Continuous plastic-film mulching increases soil aggregation but decreases soil $\mathrm{pH}$ in semiarid areas of China. Soil and Tillage Research, v.167, p.46-53, 2017. https://doi.org/10.1016/j. still.2016.11.004

Willadino, L.; Camara, T. R.; Ribeiro, M. B.; Amaral, D. O. J. do; Suassuna, F.; Silva, M. V. da. Mechanisms of tolerance to salinity in banana: Physiological, biochemical, and molecular aspects. Revista Brasileira de Fruticultura, v.39, p.1-8, 2017. https://doi. org/10.1590/0100-29452017723 